\title{
PERFORMA KONVERGENSI ANGIN PERMUKAAN DIURNAL MODEL REANALISIS ERA5 DI BENUA MARITIM INDONESIA
}

\author{
Perform of Diurnal Surface Wind Convergence of ERA5 Reanalysis Model \\ over Indonesia Maritime Continent
}

\author{
Achmad Fahruddin Rais ${ }^{1)^{\star}}$, Soenardi1), Zubaidi Fanani'), Pebri Surgiansyah') \\ 1) Badan Meteorologi Klimatologi dan Geofisika. Jl. Angkasa I No.2 Kemayoran \\ Jakarta Pusat 10720 Indonesia \\ 2) Stasiun Meteorologi Sultan Badaruddin II, Palembang \\ *E-mail: achmad.rais@bmkg.go.id
}

\begin{abstract}
Intisari
Pada penelitian ini, penulis mengkaji uji performa kualitatif konvergensi angin permukaan model reanalisis ERA5 di BMI yang dibandingkan dengan hasil penelitian menggunakan limited area model (LAM) oleh Qian, Im dan Eltahir serta Alfahmi et al. Konvergensi angin permukaan dan anomali angin permukaan dihitung dengan menggunakan finite difference. Hasil penelitian menunjukkan bahwa model reanalisis ERA5 mampu mensimulasikan konvergensi anomali angin permukaan dengan baik terhadap model regional climate model (RegCM) maupun The MIT regional climate model (MRCM) resolusi $27 \mathrm{~km}$ di Pulau Jawa dan sekitarnya serta BMI bagian barat dengan nilai konvergensi yang lebih tinggi. Sedangkan terhadap model weather research forecast (WRF) $9 \mathrm{~km}$ di BMI bagian timur, model reanalisis ERA5 juga dapat mensimulasikan konvergensi angin permukaan, tetapi dengan nilai yang lebih rendah. Selain itu, model reanalisis ERA5 mensimulasikan konvergensi angin permukaan lebih cepat 2 jam di BMI bagian barat dan timur dibandingkan MRCM27 dan WRF.
\end{abstract}

Kata Kunci: ERA5, Angin Permukaan, Konvergensi.

\begin{abstract}
In this study, we discuss the qualitative performance testing of ERA5 surface wind convergence over the Indonesia maritime continent (BMI) compared with research based on limited area model (LAM) by Qian, Im, and Eltahir and also Alfahmi et al. Wind surface convergence and wind surface anomalies convergence is calculated using finite-difference. The results show that the ERA5 reanalysis model can simulate convergence of surface wind anomalies compared with both regional climate model (RegCM) and $27 \mathrm{~km}$ MIT regional climate model (MRCM) over Java and also western $B M I$ with higher convergence values. While ERA5 reanalysis model can also simulate convergence of surface winds, but with lower values compared to $9 \mathrm{~km}$ weather research forecast (WRF) model over eastern BMI. Besides, the ERA5 reanalysis model simulates convergence of surface winds, which is 2 hours faster over western and eastern BMI compared to MRCM27 and WRF.
\end{abstract}

Keywords: ERA5, Surface Wind, Convergence.

\section{PENDAHULUAN}

Tidak seperti benua yang didominasi daratan ataupun samudera yang morfologinya hanya laut, benua maritim Indonesia (BMI) terdiri dari Pulau-Pulau yang dihubungkan oleh laut di sekitarnya. Keunikan tersebut menimbulkan karakteristik hembusan angin darat dan laut yang mencapai $400 \mathrm{~km}$ dari bibir pantai (Short et al., 2019). Bentuk garis pantainya juga mengendalikan konvergensi angin permukaan yang dapat menimbulkan presipitasi (Alfahmi et al., 2019), bahkan diidentifikasi mengontrol iklim dunia (Manabu et al., 2018). Angin darat dan laut yang berhembus di area ini dan berinteraksi dengan topografi juga membentuk karakteristik cuaca lokal (Gunawan, 2006).
Pemodelan angin permukaan di BMI dengan model cuaca dan iklim global masih menjadi hal yang menantang. Performa model cuaca dan iklim global masih dianggap tidak dapat merepresentasikan interaksi terhadap topografi dengan baik pada penelitian sebelumnya karena resolusinya yang kasar, sehingga model tersebut di-downscaling dengan mempergunakan model cuaca dan iklim area terbatas (LAM) (Qian, 2008; Hara et al., 2009; Bhatt et al., 2016; Im \& Eltahir, 2018; Alfahmi et al., 2019). Tetapi, ada salah satu model reanalisis global yang kemungkinan dapat merepresentasikan interaksi cuaca terhadap topografi karena model tersebut mengalami perbaikan kuantitas data observasi dalam proses asimilasi dan resolusi temporal serta spasial yang menggantikan ERA Interim yang sudah 
dipublikasi sejak 2006 (Hersbach et al., 2019). ERA5 adalah singkatan dari The European Centre for Medium-Range Weather Forecast (ECMWF) Reanalysis 5-th Generation. Model ERA5 adalah model renalisis cuaca global generasi ke-5 yang diproduksi oleh ECMWF dengan menggunakan asimilasi data 4D-Var CY41R2 pada Integrated Forecast System (IFS) ECMWF. Model tersebut memiliki resolusi spasial $0.25^{\circ}$ dan temporal 1 jam.

Fokus tulisan ini adalah mengetahui performa kualitatif konvergensi angin permukaan model reanalisis ERA5 di BMI yang dibandingkan dengan hasil penelitian dengan LAM oleh Qian (2008), Im \& Eltahir (2018) dan Alfahmi et al. (2019).

\section{METODE}

Data reanalisis ERA5 yang digunakan memiliki resolusi $0.25^{\circ}$ setiap jam periode 19792018. Pada tahun 2019, data lengkap setiap jam model reanalisis global ERA5 dipublikasikan melalui C3S Climate Data Store (CDS) (Raoult et al., 2017).

Konvergensi angin permukaan dihitung menggunakan central finete difference di BMI bagian timur sesuai area penelitian Alfahmi et al. (2019) pada bulan Maret. Selain menghitung konvergensi dari angin permukaan, penulis juga menghitung konvergensi dari anomali angin permukaan di Pulau Jawa dan sekitarnya serta BMI bagian barat. Pembuatan anomali angin dimaksudkan untuk menormalisasi angin background dan lebih memperlihatkan komponen disturbance yang merupakan representasi angin darat-laut seperti yang dilakukan dalam penelitian Qian (2008) pada periode Desember-JanuariFebruari (DJF) dan Im \& Eltahir (2018) pada bulan Januari.

Performa kualitatif diuji dengan membandingkan nilai pada masing-masing wilayah penelitian (Gambar 1) yang direpresentasikan oleh warna interval kelas untuk divergensi dan interval vektor untuk vektor angin. Skala interval kelas sudah disesuaikan dengan hasil penelitian Qian (2008), Im \& Eltahir (2018) serta Alfahmi et al. (2019) pada Gambar 2 s/d 8.

\section{HASIL DAN PEMBAHASAN}

\subsection{Konvergensi Anomali Angin Permukaan di Pulau Jawa}

Pada Gambar 2, konvergensi anomali angin model ERA5 tersebar di perairan sebelah utara Pulau Jawa, sebagian Selat Sunda dan perairan sebelah selatan Pulau Jawa bagian tengah. Sedangkan di Pulau Jawa, konvergensi terdistribusi tidak merata, kecuali pada bagian timur pada pukul 07-10 LT. Selanjutnya pada pukul 10-16 LT, konvergensi anomali angin tersebar di Pulau Jawa dengan nilai paling besar dibandingkan pada rentang waktu lain. Nilai konvergensi tersebut berkurang pada pukul 16-19 LT. Lain halnya pada pukul 19-07 LT, konvergensi anomali angin tersebar di perairan sekitar Pulau Jawa.

Jika pola sebaran konvergensi anomali angin model ERA5 dibandingkan dengan perubahan konvergensi anomali angin regional climate model (RegCM) dalam penelitian Qian (2008) maka terdapat kesamaan kekontrasan distribusi konvergensi di Pulau Jawa dan di perairan sekitarnya, tetapi tampak bahwa konvergensi anomali angin model ERA5 lebih cepat dibandingkan hasil RegCM.

\subsection{Konvergensi Anomali Angin Permukaan di BMI Bagian Barat}

Pada Gambar 3 s/d 5, konvergensi anomali angin mulai terjadi di Pulau Sumatera dan Jawa pukul 10 LT dan berakhir pada 19 LT. Puncak konvergensi terjadi pada pukul 14 LT, sedangkan konvergensi anomali angin terjadi di Pulau Kalimantan sampai pukul 22 LT yang lebih lama dari pulau lainnya, hal tersebut dapat disebabkan karena Pulau Kalimantan lebih luas yang dapat menyimpan panas lebih banyak sehingga gradien tekanan antara Pulau dan perairan di sekitarnya tidak cepat berubah. Konvergensi juga terjadi di perairan sekitar pulau-pulau mulai pukul 17 LT sampai pukul 08 LT.

Dibandingkan penelitian Im \& Eltahir (2018), model yang sesuai dibandingkan dengan ERA5 adalah The MIT Regional Climate Model $27 \mathrm{~km}$ (MRCM27) dibandingkan MRCM $12 \mathrm{~km}$ karena resolusinya yang hampir sama. Konvergensi anomali angin pada pukul 19 LT model MRCM27 lebih lambat dibandingkan model ERA5. Konvergensi model tersebut sesuai dengan konvergensi anomali angin model ERA5 pada pukul 17 LT. Begitu juga dengan konvergensi anomali angin pada pukul 07 LT. Secara umum nilai konvergensi anomali angin ERA5 lebih besar dari model MRCM27 baik di pulau maupun di perairan sekitarnya.

\subsection{Konvergensi Angin Permukaan BMI Bagian Timur}

Pada gambar $6 \mathrm{~s} / \mathrm{d}$ 8, distribusi konvergensi angin permukaan model ERA5 terdistribusi di Pulau Sulawesi, Kepulauan Maluku dan Papua tampak jelas mulai pukul 08 LT. Nilai konvergensi mencapai puncaknya pada pukul 11-13 LT dengan nilai mencapai $<-510^{-5} \mathrm{~s}^{-1}$. Di pegunungan Papua bagian tengah, konvergensi tampak terjadi sepanjang hari. Di perairan sekitar pulau-pulau, area konvergensi angin permukaan model ERA5 tampak jelas pada pukul 17-06 LT, kecuali konvergensi angin permukaan di Teluk Cendrawasih yang sudah terbentuk pada pukul $16 \mathrm{LT}$.

Perbandingan konvergensi angin permukaan model ERA5 terhadap konvergensi model weather research forecast (WRF) dalam penelitian Alfahmi et al. (2019) memperlihatkan bahwa model ERA5 dapat mensimulasikan konvergensi permukaan di pantai utara Teluk 
Cendrawasih dan di Pulau Sulawesi bagian selatan dan tenggara pada pukul 12 LT. Pada pukul 24 LT, konvergensi di Teluk Cendrawasih dapat disimulasikan dengan baik oleh model ERA5. Lain halnya di Teluk Tolo, konvergensi angin permukaan disimulasikan oleh model ERA5 lebih cepat 2 jam dari pada simulasi WRF dengan nilai konvergensi yang lebih kecil.

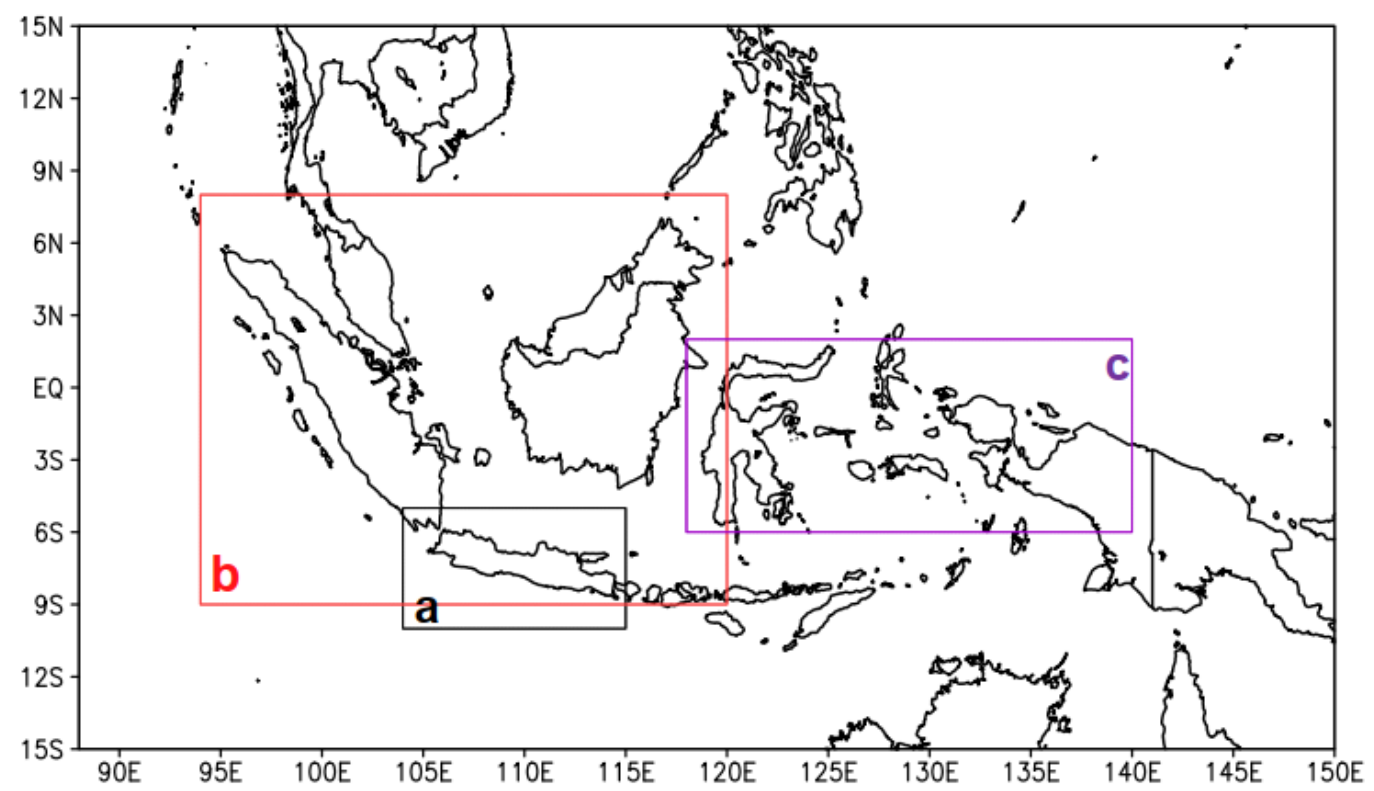

Gambar 1. Wilayah penelitian a) Qian et al. (2008), b) Im \& Eltahir (2018) dan c) Alfahmi et al. (2019).

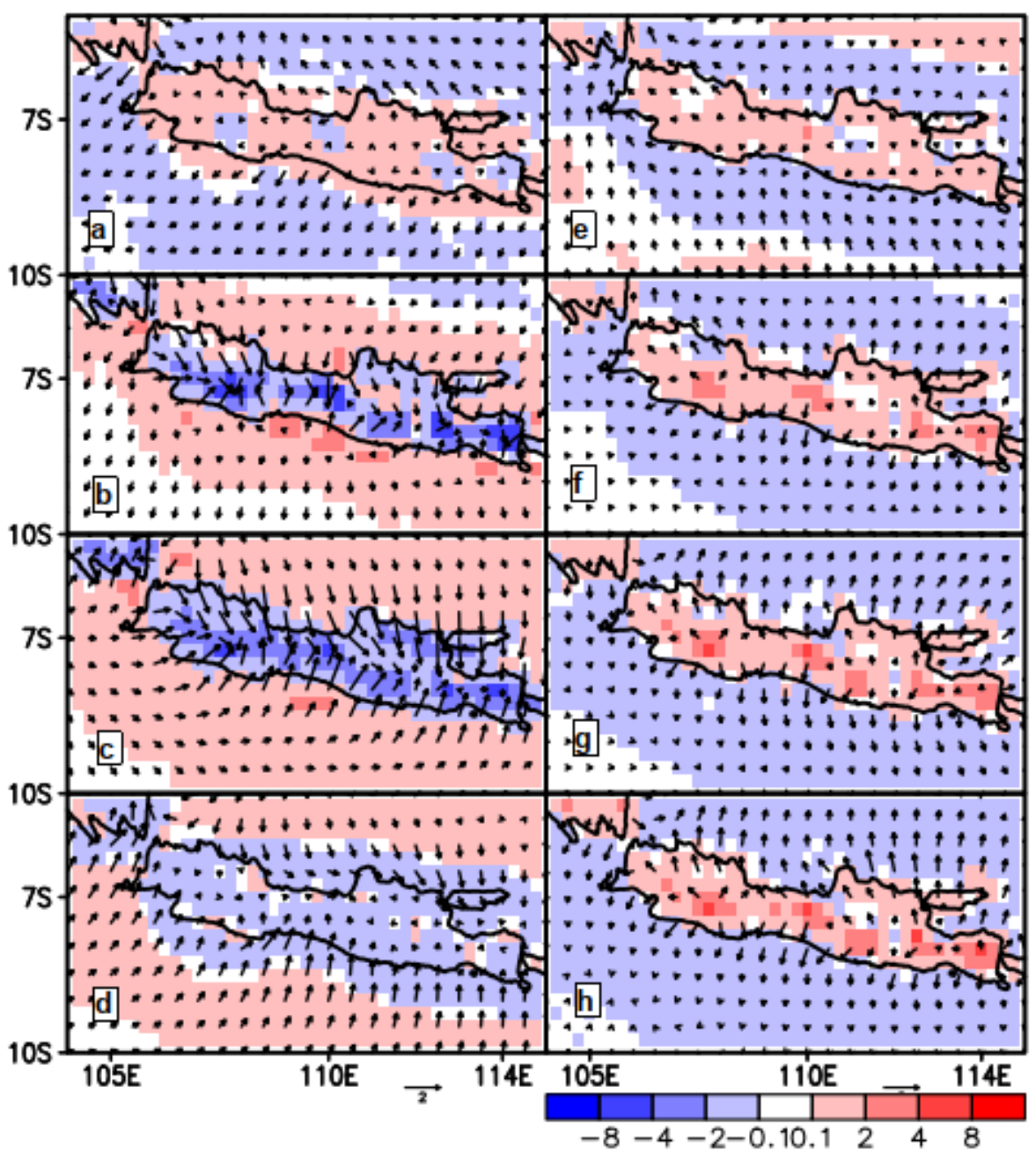

Gambar 2. Anomali angin permukaan (vektor) dan divergensinya (biru-merah) model reanalisis ERA5 di Pulau Jawa dan perairan sekitarnya pada a) 07-10 LT, b) 10-13 LT, c) 13-16 LT, d) 16-19 LT, e)19-22 LT, f) 22-01 LT, g) 01-04 LT dan h) 04-07 LT. 


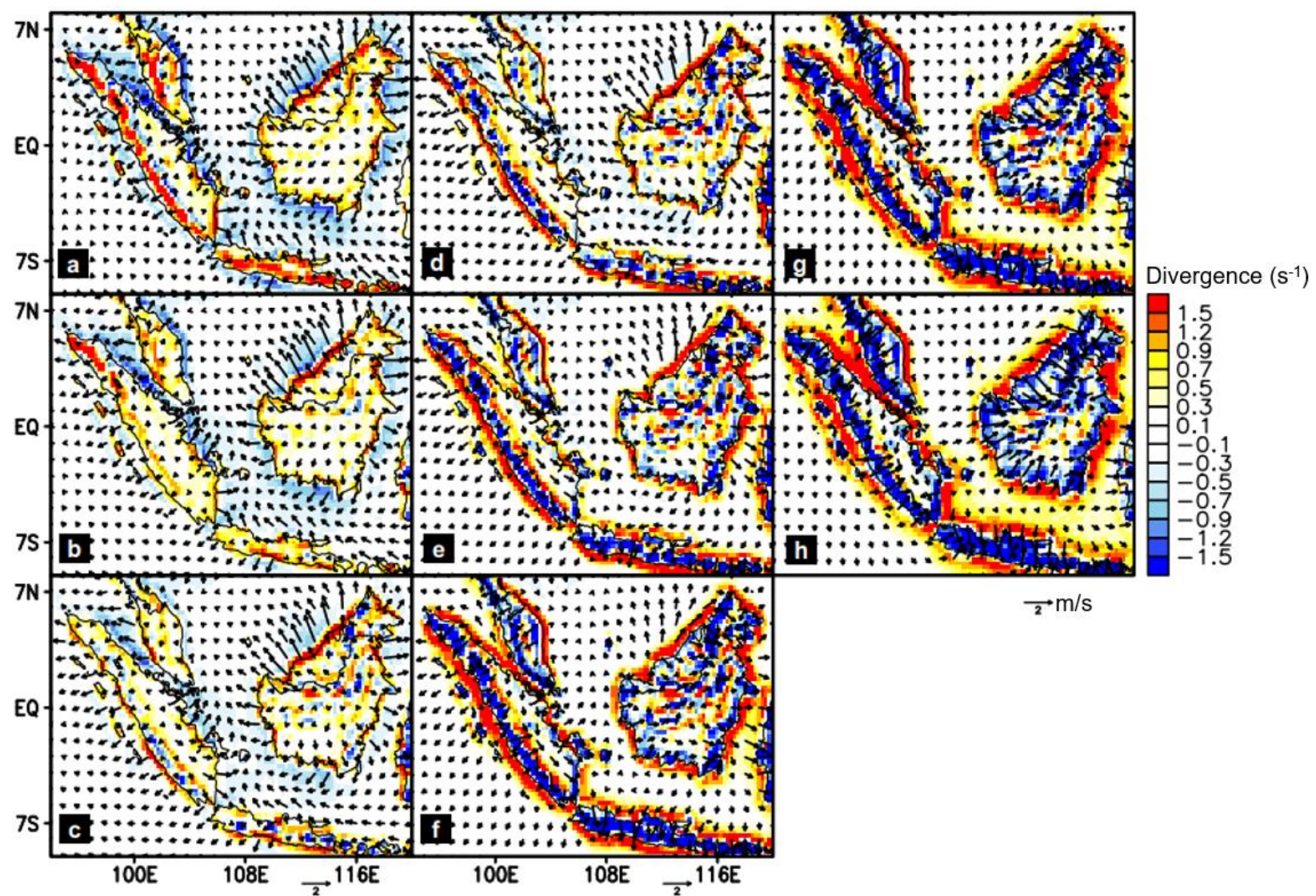

Gambar 3. Anomali angin permukaan (vektor) dan divergensinya (biru-oranye) model reanalisis ERA5 di BMI bagian barat pada a) $07 \mathrm{LT}$, b) $08 \mathrm{LT}, \mathrm{c}) 09 \mathrm{LT}$, d) $10 \mathrm{LT}$, e) $11 \mathrm{LT}, \mathrm{f}) 12 \mathrm{LT}, \mathrm{g}) 13 \mathrm{LT}$ dan h) $14 \mathrm{LT}$.

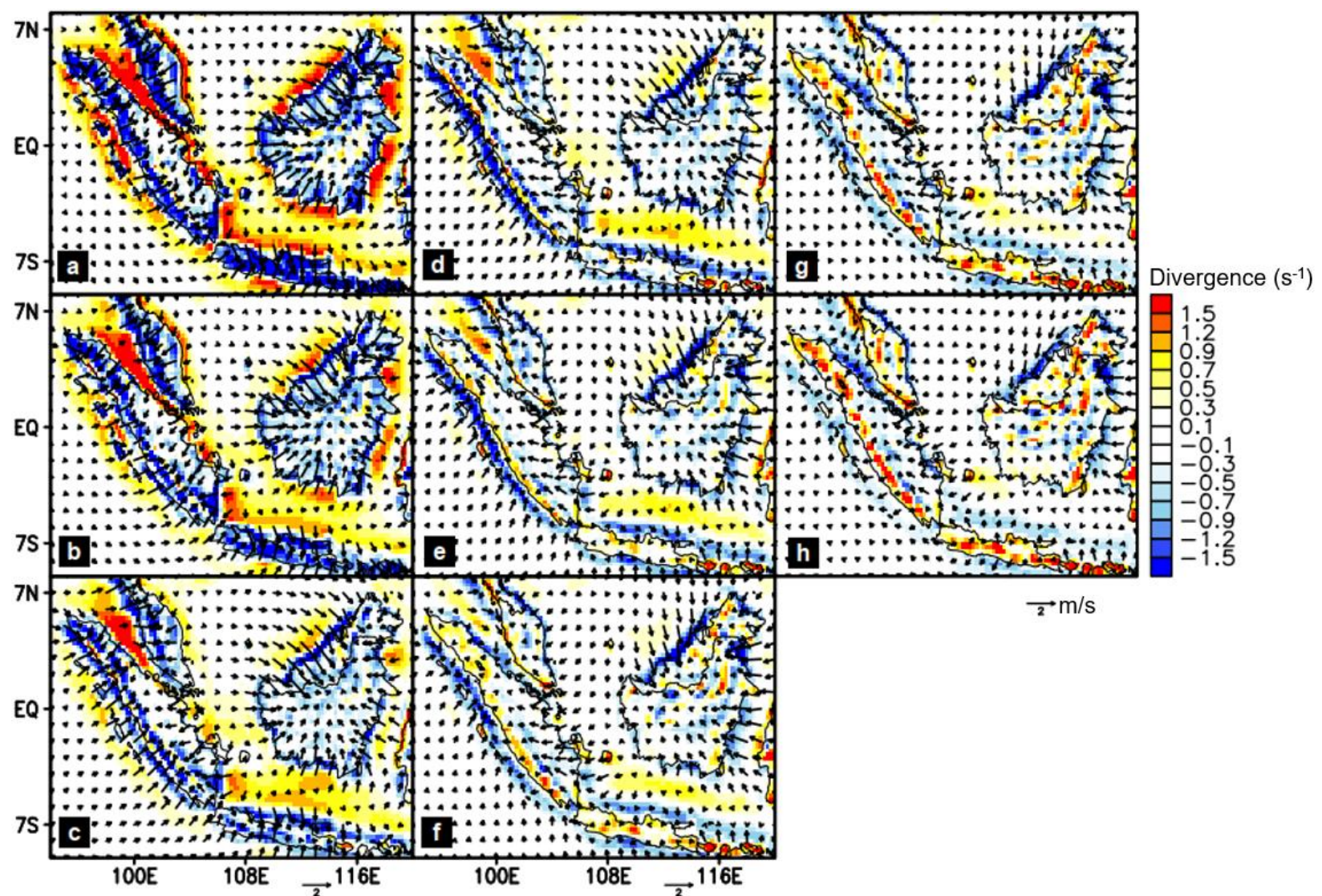

Gambar 4. Anomali angin permukaan (vektor) dan divergensinya (biru-oranye) model reanalisis ERA5 di BMI bagian barat pada a) 15 LT, b) 16 LT, c) 17 LT, d) 18 LT, e) 19 LT, f) 20 LT, g) 21 LT dan h) 22 LT. 


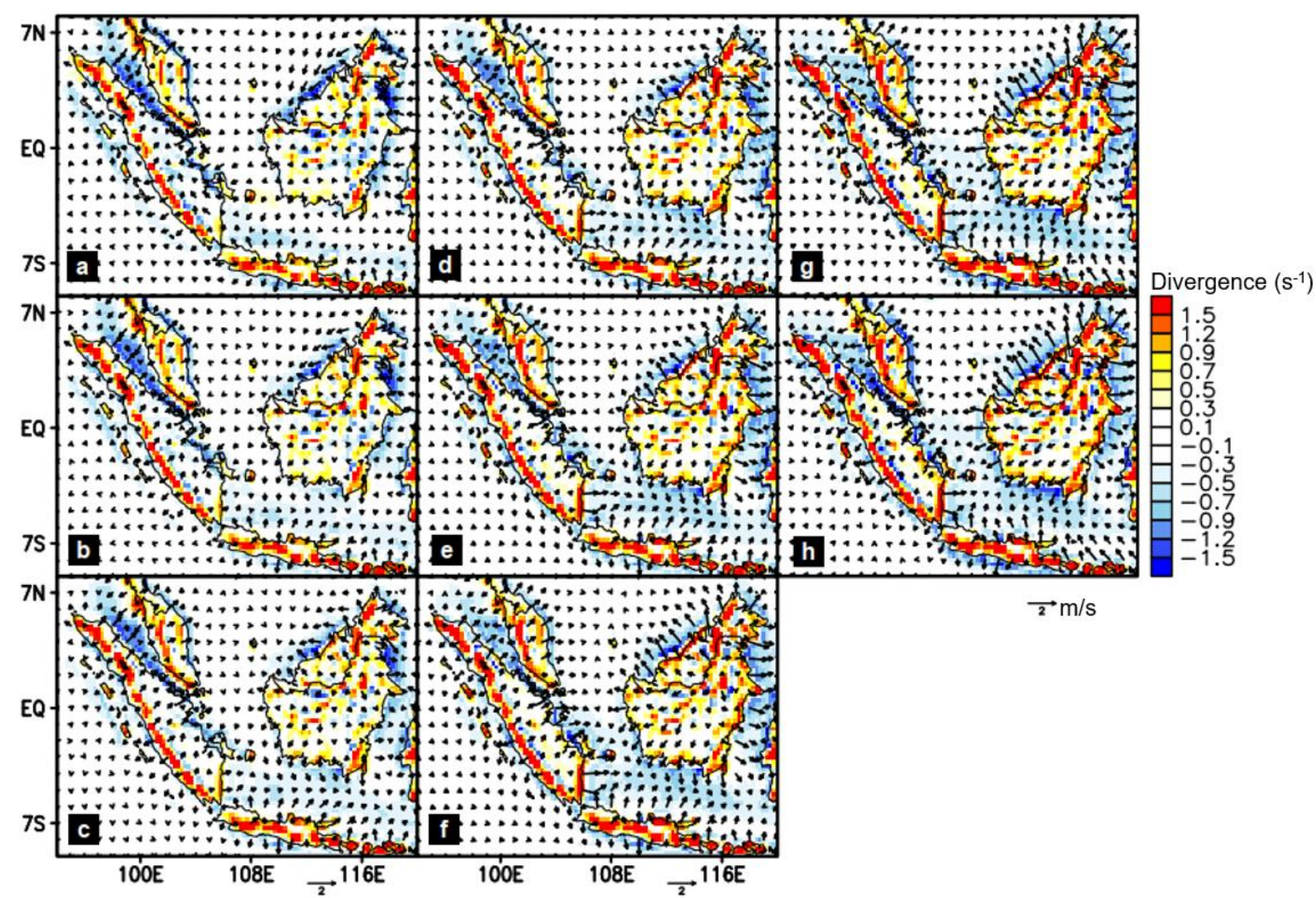

Gambar 5. Anomali angin permukaan (vektor) dan divergensinya (biru-oranye) model reanalisis ERA5 di BMI bagian barat pada a) 23 LT, b) 00 LT, c) 01 LT, d) 02 LT, e) 03 LT, f) 04 LT, g) 05 LT dan h) 06 LT.



Gambar 6. Angin permukaan (vektor) dan divergensinya (biru-oranye) di BMI bagian timur pada a) 08 LT, b) $09 \mathrm{LT}, \mathrm{c}) 10 \mathrm{LT}, \mathrm{d}) 11 \mathrm{LT}, \mathrm{e}) 12 \mathrm{LT}, \mathrm{f}) 13 \mathrm{LT}, \mathrm{g}) 14 \mathrm{LT}$ dan h) $15 \mathrm{LT}$. 


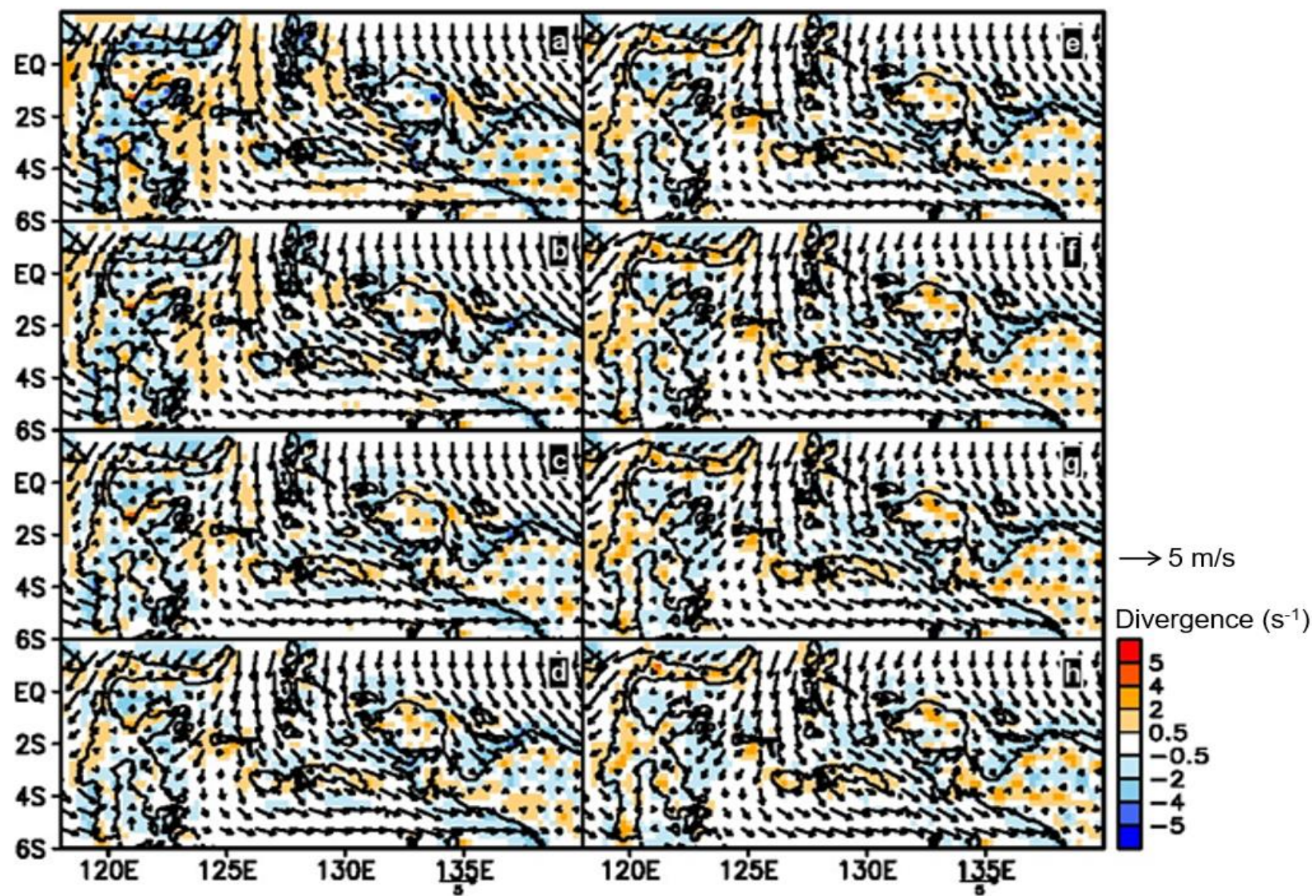

Gambar 7. Angin permukaan (vektor) dan divergensinya (biru-oranye) model reanalisis ERA5 di BMI bagian timur pada a) 16 LT, b) 17 LT, c) 18 LT, d) 19 LT, e) 20 LT, f) 21 LT, g) 22 LT dan h) 23 LT.

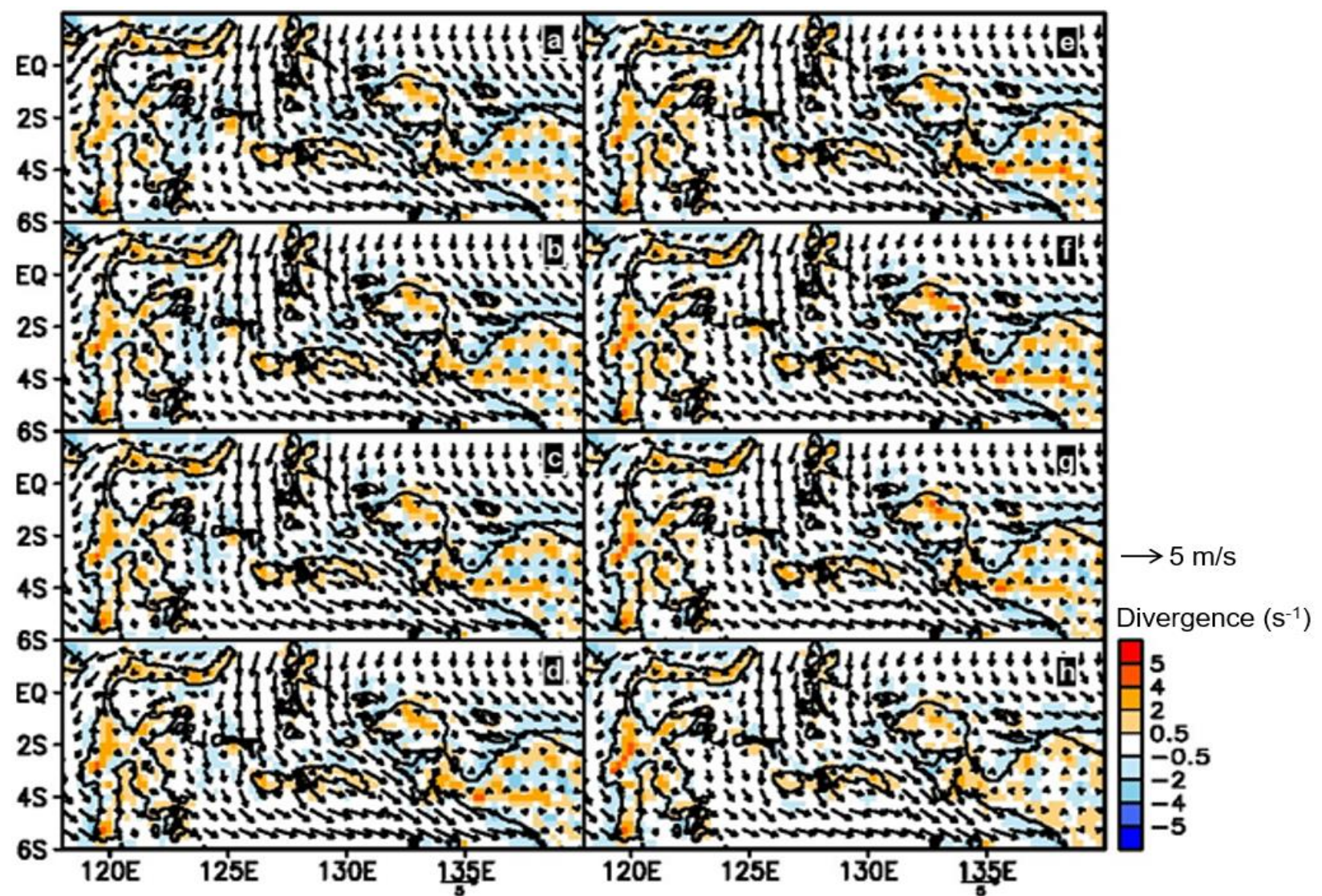

Gambar 8. Angin permukaan (vektor) dan divergensinya (biru-oranye) model reanalisis ERA5 di BMI bagian timur pada a) $00 \mathrm{LT}$, b) $01 \mathrm{LT}$, c) $02 \mathrm{LT}$, d) $03 \mathrm{LT}$, e) $04 \mathrm{LT}$, f) $05 \mathrm{LT}$, g) $06 \mathrm{LT}$ dan h) $07 \mathrm{LT}$. 


\section{KESIMPULAN}

Performa konvergensi angin permukaan model reanalisis ERA5 telah diuji dengan membandingkannya terhadap hasil penelitian Qian et al. (2008), Im \& Eltahir (2018) dan Alfahmi et al. (2019) yang menggunakan LAM. Berdasarkan Gambar 2 s/d 5, hasil analisis menunjukkan bahwa model reanalisis ERA5 mensimulasikan konvergensi anomali angin permukaan dengan baik terhadap model RegCM maupun MRCM resolusi $27 \mathrm{~km}$ di Pulau Jawa dan sekitarnya serta BMI bagian barat dengan nilai konvergensi yang lebih tinggi. Sedangkan terhadap model WRF $9 \mathrm{~km}$ di BMI bagian timur, model reanalisis ERA5 juga dapat mensimulasikan konvergensi angin permukaan, tetapi dengan nilai yang lebih rendah mengacu pada pembahasan Gambar 6 s/d 8. Selain itu, model reanalisis ERA5 mensimulasikan konvergensi angin permukaan lebih cepat 2 jam di BMI bagian barat dan timur dibandingkan MRCM27 dan WRF pada Gambar 3 s/d 8.

\section{DAFTAR PUSTAKA}

Alfahmi, F., Boer, R., Hidayat, R., Perdinan., Sopaheluwakan, A. (2019). The Impact of Concave Coastline on Offshore Distribution over Indonesian Maritime Continent. The Scientific World Journal, 2019. doi: 10.1155/2019/6839012

Bhatt, B.C., Sobolowski, S., Higuchi, A. (2016). Simulation of Diurnal Rainfall Variability over the Maritime Continent with a HighResolution Regional Climate Model. Journal of the Meteorological Society of Japan, 94A, 89-103. doi: 10.2151/jmsj.2015-052

Gunawan, D. (2006). Atmospheric Variability in Sulawesi, Indonesia - Regional Atmospheric Model Results and Observations. Disertasi. der Fakultät für
Forstwissenschaften und Waldökologie der Georg-August-Universität Göttingen.

Hara, M., Yoshikane, T., Takahashi, H.G., Kimura, F., Noda, A., Tokioka, T. (2009). Assessment of the Diurnal Cycle of Precipitation over the Maritime Continent Simulated by a $20 \mathrm{~km}$ Mesh GCM Using TRMM PR Data. Journal of the Meteorological Society of Japan, 87A, 413424. doi: 10.2151/jmsj.87A.413

Hersbach, H., Bell, B., Berrisford, P., Horányi, A., Sabater, J.M., Nicolas, J., Radu, R., Schepers, D., Simmons, A., Soci, C., Dee, D. (2019). Global reanalysis: goodbye ERAInterim, hello ERA5. ECMWF Newsletter No. 159 - Spring 2019, 17-24. doi: 10.21957/vf291hehd7

Im, E-S., Eltahir, E.A.B. (2018). Simulation of the Diurnal Variation of Rainfall over the Western Maritime Continent Using a Regional Climate Model. Climate Dynamics, 51, 73-88. doi: 10.1007/s00382017-3907-3

Qian, J-H. (2008). Why Precipitation is Mostly Concentrated over Islands in the Maritime Continent. Journal of Atmospheric Science, 65(4), 1428-1441. doi: 10.1175/2007JAS2422.1

Raoult, B., Bergeron, C., Alós, A.L., Thépaut, J-N., Dee, D. (2017). Climate Service Develops User-friendly Data Store, ECMWF Newsletter No. 151 - Spring 2017, 22-27. doi: $10.21957 / p 3 c 285$

Short, E., Vincent, C.L., Lane, T.P. (2019). Diurnal Cycle of Surface Winds in the Maritime Continent observed through Satellite Scatterometry. Monthly Weather Review, 147(6), 2023-2044. doi: 10.1175/MWR-D18-0433.1

Yamanaka, M.D., Ogino, S-Y., Wu, P.M., Jun-Ichi, H., Mori, S., Matsumoto, J., Syamsudin, F. (2018). Maritime Continent Coastlines Controlling Earth's Climate. Progress in Earth and Planetary Science 5(21). doi: 10.1186/s40645-018-0174-9 